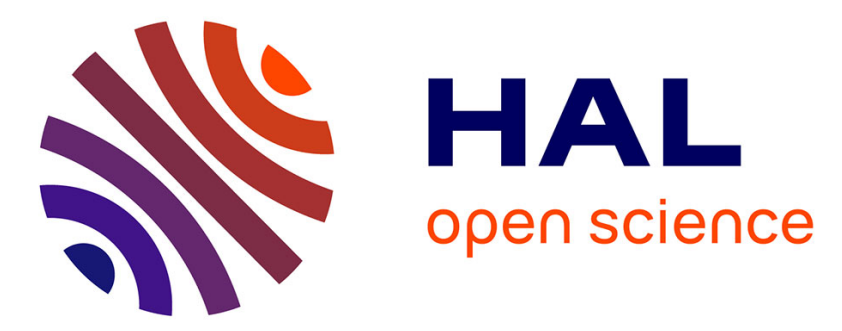

\title{
Element repertoire: change and development with age in Whitethroat song
}

\author{
Thorsten Johannes Skovbjerg Balsby, Poul Hansen
}

\section{To cite this version:}

Thorsten Johannes Skovbjerg Balsby, Poul Hansen. Element repertoire: change and development with age in Whitethroat song. Journal für Ornithologie = Journal of Ornithology, 2009, 151 (2), pp.469-476. 10.1007/s10336-009-0481-4 . hal-00568363

\section{HAL Id: hal-00568363 https://hal.science/hal-00568363}

Submitted on 23 Feb 2011

HAL is a multi-disciplinary open access archive for the deposit and dissemination of scientific research documents, whether they are published or not. The documents may come from teaching and research institutions in France or abroad, or from public or private research centers.
L'archive ouverte pluridisciplinaire HAL, est destinée au dépôt et à la diffusion de documents scientifiques de niveau recherche, publiés ou non, émanant des établissements d'enseignement et de recherche français ou étrangers, des laboratoires publics ou privés. 
Element repertoire: change and development with age in Whitethroat Sylvia communis song

Thorsten J. S. Balsby* and Poul Hansen**

*Behaviour group, Department of Biology, University of Copenhagen,

Universitetsparken 15, DK-2100 Copenhagen $\emptyset$, Denmark. E-mail:

tjsbalsby@bio.ku.dk. Phone +45 51862515

**Natural History Museum Århus, Wilhelm Meyers Allé 210, Universitetsparken,

DK-8000 Århus C, Denmark 


\begin{abstract}
Song repertoires are often important in sexual selection. In several species older males have larger repertoires than one-year old males. The development of large song repertoires within an individual is, however, poorly understood. We studied song element repertoire changes in five individual male whitethroats Sylvia communis sampled as one and two years old. Males increased the size of their element repertoire between first and second year. Song length and number of different elements per song did not change between years. Song element repertoire size, therefore, could be a reliable signal of male age. On average $44.3 \%$ of the song elements in the first year repertoire were also found in the second year repertoire. Elements, shared between years, were found earlier in the songs and tended to occur in sequences. Sequences of shared elements also seemed to be conserved between years. The study suggests that the song element repertoire in the second year is partly based on the first year repertoire, which may explain why large song repertoires mainly are expressed by males at least two-year old. Song element repertoire can thus be a reliable indication of male age.
\end{abstract}

Keywords: song repertoire, song development, age, delayed maturation, whitethroat, Sylvia communis. 


\section{Introduction}

Several oscine passerine species have very elaborate song repertoires, which may serve both inter- and intrasexual functions (Catchpole and Slater 2008). Development of large repertoires has been hypothesized to be costly (Catchpole 1996; Buchanan et al. 2004), but see Gil and Gahr (2002), and large repertoire size has been shown to reflect aspects of male quality such as age, condition and parasite (Catchpole and Slater 2008; Gil et al. 2001; Spencer et al. 2005) or nutritional stress early in life (Nowicki et al. 1998).

Cross-sectional studies have demonstrated that old males have larger song repertoires in e.g. sedge warbler Acrocephalus schoenobaenus (Birkhead et al. 1997), pied flycatcher Ficedula hypoleuca (Lampe and Espmark 1994), great tit Parus major (McGregor et al. 1981), European starling Sturnus vulgaris (Eens et al. 1992), canary Serinus canaria (Nottebohm et al. 1986), whitethroat Sylvia communis (Balsby 2000a) and red-winged blackbird Agelaius phoeniceus (Yasukawa et al. 1980). An age difference in song repertoire size could arise if older males include new elements in their repertoire or if males with larger repertoires have higher survival rates (Espmark and Lampe 1993). However, only in great tits a relation between song repertoire size and survival rate has been documented (Lambrechts \& Dhondt 1986). Longitudinal studies have shown that individual males increase their repertoire size with age, especially between first and second year, in pied flycatcher (Espmark and Lampe 1993), willow warbler Phylloscopus trochilus (Gil et al. 2001), starling (Mountjoy and Lemon 1995), sedge warbler (Nicholson et al. 2007) and great reed warbler Acrocephalus arundinaceus, although the increase in repertoire size only applied to one of the two populations of great reed warblers (Forstmeier et al. 2006). These 
longitudinal studies indicate that the repertoires only develop fully in older males in a number of species.

Longitudinal changes are interesting, because they offer insight to the development of the song repertoire and may explain why mainly older males display large repertoires. Although a large repertoire would be advantageous in both interand intra-sexual interactions, the full repertoire is often delayed to older age, even though the songs in the repertoire could have been learned early in life. One explanation may be that males can not learn a large repertoire in one season, but need to build on the repertoire from one or more previous years. This could be tested by comparing the song element repertoire between years. In this case we should expect to find that many elements and the most frequently used elements are shared between years. Shared elements should also occur in identical sequences between years. The alternative possibility is that older males develop their repertoire independently of the repertoire of previous years. In that case, elements, shared between years, should not be used more frequently than non-shared elements and sequences of shared elements should not be conserved between years.

In this paper we present data on the longitudinal change of song element repertoires and composition in the whitethroat in order to investigate how males develop their song repertoire from first to second year. Male whitethroats use their song for mate attraction and territory defence and have a substantially higher song activity before they attract a female to their territory (Balsby 2000b). Cross-sectional studies of whitethroats have shown that one-year old males had smaller song repertoires than males two-years old or older. The song element repertoire seems to be a sexually selected trait in whitethroats. Females have been found to show a preference for males with a large song repertoire (Balsby 2000a), while males did not 
respond to differences in song repertoire size in a playback experiment (Balsby and Dabelsteen 2001). Given the importance of repertoire size in sexual selection, we wanted to study the development of the repertoire size by comparing the song element repertoire in individual males as one- and two-year old

\section{Methods}

The birds in this study lived in hedge rows between agricultural fields on the south side of Fussing Lake, Denmark (56 $\left.28^{\prime} \mathrm{N}, 9^{\circ} 54^{\prime} \mathrm{E}\right)$ in May and June 1995, 1996 and 1997. To colour band and age each male, we captured the birds in mist nets by means of playback. Each male was marked with a unique combination of colour rings and one metal ring for individual identification. One-year old males could be distinguished from older males on the basis of iris colour and moulting patterns (Karlson et al. 1985; Svensson 1992). In total we colour banded 9 one-year old males and recorded their song. The following year we identified 5 of these males by their colour bands and recorded their song. We recorded and analysed a total of 7021 songs from the 5 males. We analysed an average of 813 songs (range 196 to 1162 songs) from one-year old males and an average of 590 songs (range 440 to 729 songs) from the same males in their second year. We recorded all males with a Sennheiser MKT 816T directional microphone and a Sony 5000 EMV tape recorder. All recordings took place between 0500 and $1200 \mathrm{~h}$. Males were only recorded prior to attraction of a female, as song activity post female attraction is very scarce. For the spectrographic analysis we used Avisoft-SASLab Pro (www.avisoft.de). We sampled sounds at 22.05 kHz. Spectrograms were made with the hamming window, a time resolution of $5.8 \mathrm{~ms}$ and a bandwidth of $111 \mathrm{~Hz}$. 
We classified all song elements by visual comparison between spectrograms on the computer screen and a printed catalogue with all known song elements for each of the males (Fig. 1). Each song element was classified either as an already existing type or as a new type. As the analysis progressed we assigned each new element a unique number in the catalogue and printed them for the catalogue. Elements were categorized on basis of shape, frequency and length; elements were only categorized as different if the changes were distinctly different and not gradual. All elements could be categorized. The recordings of one-year and two-year old males were analysed separately.

We measured song length (as number of elements), number of different elements per song, rep1000 and max1000. Rep1000 measured the average number of different elements presented within 1000 elements calculated over the whole sequence at steps of 10 elements. Max1000 was the maximum number of different elements within 1000 elements found while calculating the rep1000 (Balsby 2000a). An estimate of the full repertoire may be obtained from a cumulative graph such as Fig. 2 if the graph approximated an asymptote (Kroodsma 1982). However, in the whitethroat most males continued to present new song elements even after more than 10,000 elements had been analysed (Balsby 2000a). Contrary to rep1000 and max 1000, an estimate of the song element repertoire based on the cumulative graph would, therefore, depend on the number of elements analysed. Rep1000 and max1000 were, therefore, assumed to be a better measure, also for comparison between males and years.

We then compared the catalogue for the two years for each male to identify elements used in both years (shared elements) and elements that were only found in either first or second year (non-shared elements). We then translated each sequence so 
the element numbers as one-year old and two-year old referred to the same element for shared elements. From the translated sequence we quantified the sequential organization of the song (i.e. the number of times a combination of elements occurred in a particular sequence). For shared and non-shared elements we counted their frequency, the average position in the song of shared and non-shared elements measured as the number of elements counted from the start of each song. We also counted the number of times a sequence of shared elements occurred. This enabled us to compare the sequences and the use of shared elements between years within an individual.

\section{Statistics}

We used StatXact (Cytel Software Cooperation) for making the randomisation tests for comparison of two paired groups. Each test was based on 1000 resamplings and we report the exact p-value. For other tests, we used non-parametric statistics in accordance with Siegel and Castellan (1988). In the sequence analysis, and element sharing we chose to test each test bird separately, because we were concerned about the individual pattern. This could give rise to issues with multiple testing, but most tests would still be significant after sequential bonferoni corrections (Rice 1987). For comparison of sequence matrices between years we used Mantel test for skew symmetric case (Mantel 1969). All tests are two-tailed.

\section{Results}

\section{Song element repertoire size}

All 5 males had larger song element repertoire as two-year old (Fig. 2), despite more elements had been analysed for the one-year old males except in one. The cumulative 
graph for one-year old males almost reached an asymptote, providing a good estimate of the song element repertoire size, while the cumulative graphs for two-year old males did not reach an asymptote, and thus underestimated the element repertoire size. Despite the underestimate of the repertoire for 4 of the two-year old males, from which we analysed most elements as one year old, the total number of different elements increased at least 1.6-4.3 times from the first to the second year. Rep1000 and max 1000 supported these observations, as two-year old males had significantly larger rep1000 and max 1000 than one-year old males (Fig. 3a, b, respectively. Randomization test accounting for paired design: rep100: $\mathrm{p}<0.01$; $\max 1000: \mathrm{p}<0.01$ ). However, song length and number of different elements per song did not differ between years (Fig. 3c, d, resp. Randomization test accounting for paired design: song length: $p=0.13$; number of different elements per song: $p=0.13$ ).

\section{Comparison of element repertoires in one and two years old males}

Elements shared between years on average constituted $44 \%$ (range 30 to $61 \%$ ) of the repertoire in one-year old males (Fig. 4), but on average only $20 \%$ (range 7 to $27 \%$ ) of the repertoire in two-year old males. Four of the one-year old males used shared elements significantly more frequently than non-shared elements (Mann-Whitney U test for each male: $U \geq 3216, n_{\text {shared }} \geq 97, n_{\text {non-shared }} \geq 118 p<0.001$ ), while this was not the case for the last male, \#5 (Mann-Whitney $U$ test: $U=1353, \mathrm{n}_{\text {shared }}=38, \mathrm{n}_{\text {non-shared }}=88$, $\mathrm{p}=0.09$ ). As two-year old, four of the males (\#1 to 4) also used shared elements more frequently than non-shared elements (Mann-Whitney $U$ test: $U \geq 36662, n_{\text {shared }} \geq 97$, $\mathrm{n}_{\text {non-shared }} \geq 431 \mathrm{p}<0.001$ ), whereas one male (\#5) used non-shared elements more often than shared elements (Mann-Whitney $U$ test: $U=12355, n_{\text {shared }} \geq 38, n_{\text {non-shared }} \geq 510$ $\mathrm{p}=0.04)$ 
Shared elements on average occurred earlier in the sequence of the song elements than non-shared elements in males \#1-4 in both years (Mann-Whitney U test, one-year old: $U \geq 5.02 \times 10^{5}, \mathrm{n}_{\text {shared }} \geq 1844, \mathrm{n}_{\text {non-shared }} \geq 422, \mathrm{p}<0.0001$; Mann-Whitney $U$ test, two-year old: $\left.U \geq 1.27 \times 10^{5}, \mathrm{n}_{\text {shared }} \geq 2249, \mathrm{n}_{\text {non-shared }} \geq 1436, \mathrm{p}<0.002\right)$. In male \#5 shared elements occurred later in the song than non-shared elements in both years (Mann -Whitney U test, one-year old: $\mathrm{U}=1.59 \times 10^{6}, \mathrm{n}_{\text {shared }}=1079, \mathrm{n}_{2}=9983, \mathrm{p}<0.0001$; Mann-Whitney U test, two-year old: $\mathrm{U}=1.77 \times 10^{6}, \mathrm{n}_{\text {shared }}=453, \mathrm{n}_{\text {non-shared }}=8413$, $\mathrm{p}=0.018)$.

Songs generally started with a shared element more frequently than one would expect based on the frequency of shared elements in each males' repertoire. The expected frequencies were thus calculated on basis of the proportion of shared and non-shared elements. All two-year old males used shared elements as the first element in the song more frequently than expected from the proportion of shared elements in their repertoire (Fig. 5, $\chi 2=3284.6, \mathrm{df}=4, \mathrm{p}<0.001$ ). In one-year old males the pattern was less clear as four of the males (\#1-4) used shared elements as the first element in the song more often than expected from the proportion of shared elements in their repertoire and one male (\#5) used shared elements as first song element less often than expected from the proportion of shared elements in its repertoire (Fig. 5, $\chi 2=3199, \mathrm{df}=4, \mathrm{p}<0.001)$

First-order transition of shared elements showed some stability between years. Overall, shared elements tended to be followed by shared elements and non-shared elements tended to be followed by non-shared elements in both years for all the males (Chi-square test, one-year old: $\chi 2>1180, \mathrm{df}=1, \mathrm{p}<0.001$; two-years old: $\chi 2>213, \mathrm{df}=1$, $\mathrm{p}<0.001)$. Dyads of shared elements tended to occur in identical sequences between years, as shown by the correlation between the frequency of the combinations of the 
first-order transitions in the first and second year for each male (Mantel test for asymmetric matrices, male $1: \mathrm{t}=50 \mathrm{r}=0.29$, male $2 \mathrm{t}=59 \mathrm{r}=0.19$, male $3: \mathrm{t}=114 \mathrm{r}=0.35$, male 4: $\mathrm{t}=96 \mathrm{r}=0.33$, male $5: \mathrm{t}=3.9 \mathrm{r}=0.17$, $\mathrm{df}$ for all $\infty$, all $\mathrm{p}<0.001$ ). Thus, sequences of pairs of elements were conserved between years. Furthermore, the longest sequence of shared elements that were identical between years were 4, 13, 16, 11 and 3 elements for male \# 1 to 5, respectively.

\section{Discussion}

Male whitethroats increased their song element repertoire between the first and the second year of life, as also shown by the increased rep1000 and max1000. We have no data to quantify the change in repertoire size after the second year. However, the repertoire size of the two-year old males in this study were larger than the measured repertoire sizes in an earlier study (Balsby 2000a), in which the songs from 10 males, two years old or older, were analysed. We, therefore, believe that the major change in repertoire size in whitethroats occurs between first and second year, which would be similar to willow warblers (Gil et al. 2001). The increase in repertoire size with age fits with other studies (Gil et al. 2001, Nicholson et al. 2007, Forstmeier et al. 2006, and Mountjoy and Lemon 1995). However, repertoire change with age did not occur in some populations of the great reed warbler (Forstmeier et al. 2006). In nightingales Luscinia megarhynchos two-year or older males did not increase their repertoire size in the subsequent year (Kipper et al. 2004). By cross-sectional comparison Kiefer et al. (2006) showed that one-year old males had smaller repertoires than older males. This was confirmed by a longitudinal study (Kiefer et al. 2009) that showed, that one-year old males had an increased repertoire the next year.

Song repertoires may be costly to produce and maintain (Catchpole 1996; Gil and 
Gahr 2002), and evidence for a link between song repertoire size and brain size has been found in some species (Szekely et al. 1996; Airey et al. 2000; Buchanan et al. 2004), but not always (Leitner and Catchpole 2004). The present study clearly indicates that one-year old whitethroat males do not express a full repertoire, which may suggest that one-year old whitethroat males may have insufficient brain capacity to express large song repertoires. Song repertoire size in whitethroats could thus provide a reliable cue to male age. The relation between age and repertoire size could have implications for female mate choice, because age may indicate the indirect (genetic) quality of the male (Manning 1988, Kokko 1998). Female whitethroats indeed seem to prefer older males as all old males succeed in attracting a female, whereas half of the one-year old males never attracted a female (Balsby 2000a). Song repertoire size may, therefore, be a sexually selected trait in whitethroats.

In whitethroats differential survival of males with large song repertoire size (Espmark and Lampe 1993) cannot explain the repertoire difference between age-classes, as the total repertoire size (Fig. 2) of one-year old and two-year old whitethroat males does not overlap in this study and in a cross sectional study (Balsby 2000a). Song length and number of different elements per song did not differ between first and second year in cross-sectional (Balsby 2000a) and longitudinal studies (the present study). Song length and number of different elements in the song thus hold no potential for indicating age in whitethroat males.

\section{Song repertoire development}

Despite a considerable interest in the function of and the evolution of large song repertoires, their development between years has not been studied. We investigated the development of song element repertoire in the whitethroat by quantifying the 
degree of element sharing between the two years and the use of shared elements. In whitethroats a substantial part of the element repertoire consisted of elements shared between years. Both one-year and two-year old males, except one male, used shared song elements more frequently than expected from the proportion of shared song elements in the song repertoire. Shared elements also came in sequences, and at least dyads (the sequence of two elements) seemed to be conserved between years. Long identical sequences of song elements between years suggest that longer sequences of shared elements to some degree are transferred between first and second year. Male whitethroats, therefore, partly build their song element repertoire as two-year old on the song element repertoire and sequences used as one-year old. Repertoire turnover between years has also been found in sedge warblers and pied flycatchers, which drop some and include other syllables between years (Nicholson et al. 2007, Espmark and Lampe 1993). None of these studies, however, proceed to look at how the repertoires develop, but they suggest that turnover of part of the repertoire between years occur in several species besides whitethroats. Our song recordings of two-year old males have not sampled all elements in the repertoire of individual males, so there might be more shared elements. However, more shared elements would only support the conclusion that males base their repertoire as two-year old on their repertoire in the first year.

The large change in repertoire size and the recombination of the sequence of song elements between one-year and two-year old males suggest that males modify and to some degree rebuild their repertoire before the second breeding season. The rebuilding of the repertoire from first to second year would be in accordance with the seasonality of the size of various brain centres. In canaries the song controlling parts of the brain grow prior to the start of the breeding season (Nottebohm et al. 1986, Ball et al. 2004). 
The majority of songs given by whitethroats starts with a motif and ends with a variable part (Balsby 2000b). These motifs are conserved within years. Elements, shared between years, tended to occur earlier in the song than non-shared elements, suggesting that many of the shared elements were motif elements. The lack of complete motif sharing between years suggests that males modify their motif repertoire each year. Males may make this modification in order to adjust to the motifs of neighbours, thus allowing matched countersinging. Such adjustment to the song types of neighbours are known from sedge warblers (Nicholson et al. 2007). Furthermore, in great tits, wrens (Troglodytes troglodytes), dusky warbler (Phylloscopus fuscatus) and nightingales males share a substantial part of their repertoire with their neighbours (McGregor and Krebs 1989; Catchpole and Rowell 1993; Forstmeier and Balsby 2002; Griessmann and Naguib 2002). Whitethroats are generally philopatric (Hansen 1976; Cramp 1992). One of the males in this study used shared elements less often than the other four males. In the second year this male (\#5) settled in a territory about $1 \mathrm{~km}$ from his old territory. By moving, male \#5 might have had to change a much larger part of his repertoire than males that returned to the same territory as the year before. The other four males returned to the same area in both years.

Whitethroats might have learned all the song elements in an early sensitive phase, but without the capability to express them all as one-year old. Such a scenario would be similar to that found in nightingales, where males learn more song types than they express (Todt and Geberzahn 2003). However, whitethroat males stop singing once mated and only males with small repertoires, which did not attract a female, would continue singing (Balsby 2000b). Opportunities for learning song from large repertoire males would, therefore, be quite limited. A sensitive song learning 
period shorter than one year thus seems unlikely. Male whitethroats could acquire parts of their repertoire in the winter quarters or during migration similar to the marsh warbler (Acrocephalus palustris) (Dowsett-Lemaire 1979). All these possibilities require whitethroat males to be open-ended learners or to have a sensitive period for song learning that lasts at least two years. The current data set does not allow discrimination between these two possibilities. However, it is clear that the song element repertoire size is a delayed matured trait (Dale et al. 1999), as whitethroats only can express a large repertoire when two-years old or older, and as they partly build their second year song element repertoire on the first year repertoire.

\section{Zusammenfassung}

\section{Altersabhängige Entwicklung und Veränderung von Gesangselementen und -repertoiren bei Dorngrasmücken Sylvia communis}

Gesangsrepertoire sind häufig von Bedeutung für sexuelle Selektion. In einigen Vogelarten haben ältere Männchen größere Repertoire als einjährige Männchen. Die Entwicklung eines großen Repertoires innerhalb Individuen ist jedoch weniger gut untersucht. Wir haben Veränderungen von Elementen im Gesangsrepertoire von individuellen, ein- und zwei Jahre alten Dorngrasmücken untersucht. Männchen vergrößerten ihr Elementrepertoire zwischen dem ersten und dem zweiten Jahr. Gesanglänge und Anzahl unterschiedlicher Elemente pro Gesang veränderten sich nicht zwischen den Jahren. Deshalb könnte die Größe des Gesangsrepertoirs in Männchen zuverlässig Alter anzeigen. Im Schnitt wurden 44.3\% der Gesangselemente der Repertoire von einjährigen Vögeln auch im jeweils zweiten Jahr gefunden. Elemente die zwischen den Jahren gleich blieben traten früher in den Gesängen gefunden und traten auch in Sequenzen auf. Solche Sequenzen von geteilten Elementen scheinen zwischen den Jahren erhalten zu bleiben. Unsere Arbeit lässt vermuten, dass das Gesangselementrepertoire im zweiten Jahr teilweise auf das Repertoire im ersten Jahr basiert. Dies kann möglicherweise erklären warum große Gesangsrepertoire vorwiegend in Männchen die zumindest zwei Jahre alt sind, gefunden werden. Wir schließen daraus dass das Gesangsrepertoire ein zuverlässiger Indikator für das Alter eines Männchens sein kann. 


\section{Acknowledgement.}

The bird banding was done under permission from the ringing centre at the Zoological Museum, Copenhagen, Denmark. The ringing centre also provided the metal rings for ringing the whitethroats. We thank the landowners and the hunters in Venning for allowing us to study the whitethroats on their properties. TJSB is supported by a Steno stipend from the Danish Natural Science Research Council. This project complies with the laws of Denmark. The authors wish to thank the reviewers for their comments.

\section{References}

Airey DC, Buchanan KL, Szekely T, Catchpole CK, DeVoogd TJ (2000) Song, sexual selection, and a song control nucleus $(\mathrm{HVc})$ in the brains of European sedge warblers. J Neurobiol 44:1-6

Ball, GF, Auger, CJ, Bernard, DJ, Charlier, TD, Sartor, JJ, Riters, LV, Balthazart J (2004) Seasonal plasticity in the song control system. Multiple brain sites if steroid hormone action and the importance of variation in song behavior. Ann. N.Y. Acad. Sci. 1016: 586-610

Balsby TJS (2000a) Song activity and variability in relation to male quality and female choice in whitethroats Sylvia communis. J Avian Biol 31:56--62

Balsby TJS (2000b) The function of song in whitethroats Sylvia communis.

Bioacoustics 11:17-30 
Balsby TJS, Dabelsteen T (2001) The meaning of song repertoire size and song length to male whitethroats Sylvia communis. Behav Process 56:75-84

Birkhead TR, Buchanan KL, Devoogd TJ, Pellatt EJ, Szekely T, Catchpole CK (1997) Song, sperm quality and testes asymmetry in the Sedge Warbler. Anim Behav 53:965-971

Buchanan KL, Leitner S, Spencer KA, Goldsmith AR, Catchpole CK (2004) Developmental stress selectively affects the song control nucleus HVC in the zebra finch. Proc R Soc Lond B 271:2381-2386

Catchpole CK, Rowell A (1993) Song sharing and local dialects in a local population of the European wren Troglodytes troglodytes. Behaviour 125:67-78

Catchpole CK, Slater PJB (2008) Bird song, biological themes and variation.

Cambridge University Press, Cambridge

Catchpole CK (1996) Song and female choice: good genes and big brains? Trends Ecol Evol 11:358-360

Cramp, S ed. (1992) The birds of Western Paleartic Vol. VI. Oxford University Press, Oxford 
Dale S, Slagsvold T, Lampe HM, Sætre G-P (1999) Population divergence in sexual ornaments: the white forehead patch of Norwegian pied flycatchers is small and unsexy. Evolution 53:1235-1246

Dowsett-Lemaire, F. (1979). The imitative range of the song of the marsh warbker Acrocephalus palustris, with special reference to imitations of African birds. Ibis 121, 453-468.

Eens E, Pinxten R, Verheyen RF. (1992) No overlap in song repertoire size between yearling and older starlings (Sturnus vulgaris). Ibis 134:72-76

Espmark YO, Lampe HM (1993) Variations in the song of the pied flycatcher within and between breeding seasons. Bioacoustics 5:33-65

Forstmeier W, Hasselquist D, Bensch S, Leisler B (2006) Does song reflect age and viability? A comparison between two populations of the great reed warbler Acrocephalus arundinaceus. Behav Ecol Sociobiol 59:634-643

Forstmeier W, Balsby TJS (2002) Why mated dusky warblers sing so much: territory guarding and male quality announcement. Behaviour 139:89-111

Gil D, Cobb JLS, Slater PJB (2001) Song characteristics are age dependent in the willow warbler Phylloscopus trochilus. Anim Behav 62:689-694 
Gil D, Gahr M (2002) The honesty of bird song: multiple constraints for multiple traits. Trends Ecol Evol 17:133-141

Griessmann B, Naguib M (2002) Song sharing in neighbouring and non-neighbouring thrush nightingales and its implication for communication. Ethology 108:377-387

Hansen K (1976) Tornsangeren på Hjelm. Unpubl report (in Danish)

Karlson L, Persson K, Walinder G (1985) Fotografisk dokumentation av ålders- och könsskillnader hos fåglan - målsättning, arbetssätt och exempel på resultat (Photografic documentation of age and sex differences in birds - aims, methods and examples of results). Vår Fågelvärld 44:465-478

Kiefer S, Spiess A, Kipper S, Mundry R, Sommer C, Hultsch H, Todt D (2006) First-year common nightingales (Luscinia megarhynchos) have smaller song-type repertoire sizes than older males. Ethology 112:1217-1224

Kiefer S, Sommer C, Scharff C, Kipper S, Mundry R (2009) Tuning towards tomorrow? Common nightingales Luscinia megarhynchos change and increase their song repertoires from the first to the second breeding season. J Avian Biol. 40:231-236

Kipper S, Mundry R, Sommer C, Hultsch H, Todt D (2004) Long term persistence of song performance rules in nightingales (Luscina megarhynchos): a longitudinal field study on repertoire size and composition. Behaviour 141:371-390 
Kokko H (1998) Good genes, old age and life history trade-offs. Evol Ecol $12: 739-750$

Kroodsma DE (1982) Song repertoires: problems in their definition and use.

In: Kroodsma DE and Miller EH (eds) Acoustic communication in birds, Vol. 2. Academic Press, New York, pp 125-146

Lambrechts M. \& Dhondt AA (1986) Male quality, reproduction, and survival in the great tit (Parus major). Behav Ecol Sociobiol 19: 57-63

Lampe HM, Espmark YO (1994) Song structure reflects male quality in pied flycatchers (Ficedula hypoleuca). Anim Behav 47:869-876

Leitner S, Catchpole CK (2004) Syllable repertoire and the size of the song control system in captive canaries (Serinus canaria). J Neurobiol 60:21-27

McGregor PK, Krebs JR, Perrins CM (1981) Song repertoires and lifetime reproductive success in the great tit (Parus major). Am Nat 118:149-159

McGregor PK, Krebs JR (1989) Song learning in adult great tits (Parus major) the effect of neighbours. Behaviour 108:139-159

Manning JT (1985) Choosy females and correlates of male age. J Theor Biol $116: 349-354$ 
Mantel N (1969) The detection of disease clustering and a generalized regression approach. Cancer Res 27:209-220

Mountjoy DJ, Lemon RE (1995) Extended song learning in wild European starling. Anim Behav 49:357-366

Nicholson JS, Buchanan KL, Marshall RC, Catchpole CK (2007) Song sharing and repertoire size in the sedge warbler, Acrocephalus schoenobaenus: changes within and between years. Anim Behav 74:1585-1592

Nottebohm F, Nottebohm ME, Crane L (1986) Developmental and seasonal changes in canary song and their relation to changes in the anatomy of song-control nuclei. Behav Neural Biol 46:445-471

Nowicki S, Peters S, Podos J (1998) Song learning, early nutrition and sexual selection in songbirds. Am Zool 38:179-190

Rice, W.R. (1987). Analysing tables of statistical tests. Evolution, 43, 223-225.

Siegel S, Castellan NJ (1988) Nonparametric statistics for the behavioral sciences. McGraw-hill International Editions, New York Spencer KA, Buchanan KL, Goldsmith AR, Catchpole CK (2005) Parasites affect song complexity in a songbird Proc R Soc Lond B 272:2037-2043 
Svensson L (1992) Identification Guide to European Passerines (4th ed). Stockholm.

Szekely T, Catchpole CK, Devoogd A, Marchl, Z, Devoogd T (1996) Evolutionary changes in a song control area of the brain (HVC) are associated with evolutionary changes in song repertoire among European warblers (Sylviidae). Proc R Soc Lond B 263:607-610

Todt D, Geberzahn N (2003) Age dependent effects of song exposure: song crystallization sets a boundary between fast and delayed vocal imitation. Anim Behav 65: $971-979$

Yasukawa K, Blank, JL, Patterson CB (1980) Song repertoires and sexual selection in the red-winged blackbird. Behav Ecol Sociobiol 7:233-238 


\section{Figure legends}

Figure 1. Spectrogram of two motif songs from the same male. Numbers in the upper part of the spectrogram indicate the classification of song elements. Notice that the motif is identical in the two songs. The spectrograms were made with Avisoft SASLab Pro (Hamming window, Settings: FFT=256, Overlap=75).

Figure 2. Cumulative graph of the number of new song elements as a function of the number of elements analysed. Thick lines represent one-year old males, thin lines the same males as two-year old. The numbers at the end of each line indicate the identity of the male. Individuals are referred to with the same numbers in the following figures and in the text. 
Figure 3. Change between one-year old and two-year old males in rep1000 (a), max1000 (b), song length (c) and number of different elements per song (d). Numbers on the right side of the graph identify the males.

Figure 4. Number of elements found only in the first year (white), in both years (dots), and only in the second year (grey). The numbers in each of the boxes indicate the number of elements in each category. Male identity numbers as in Fig. 2 and 3.

Figure 5. Observed (grey) and expected (white) number of shared elements used as the first element in the song by each male as one and two years old. Male identity numbers as in Fig. 2-4.

Figure 1
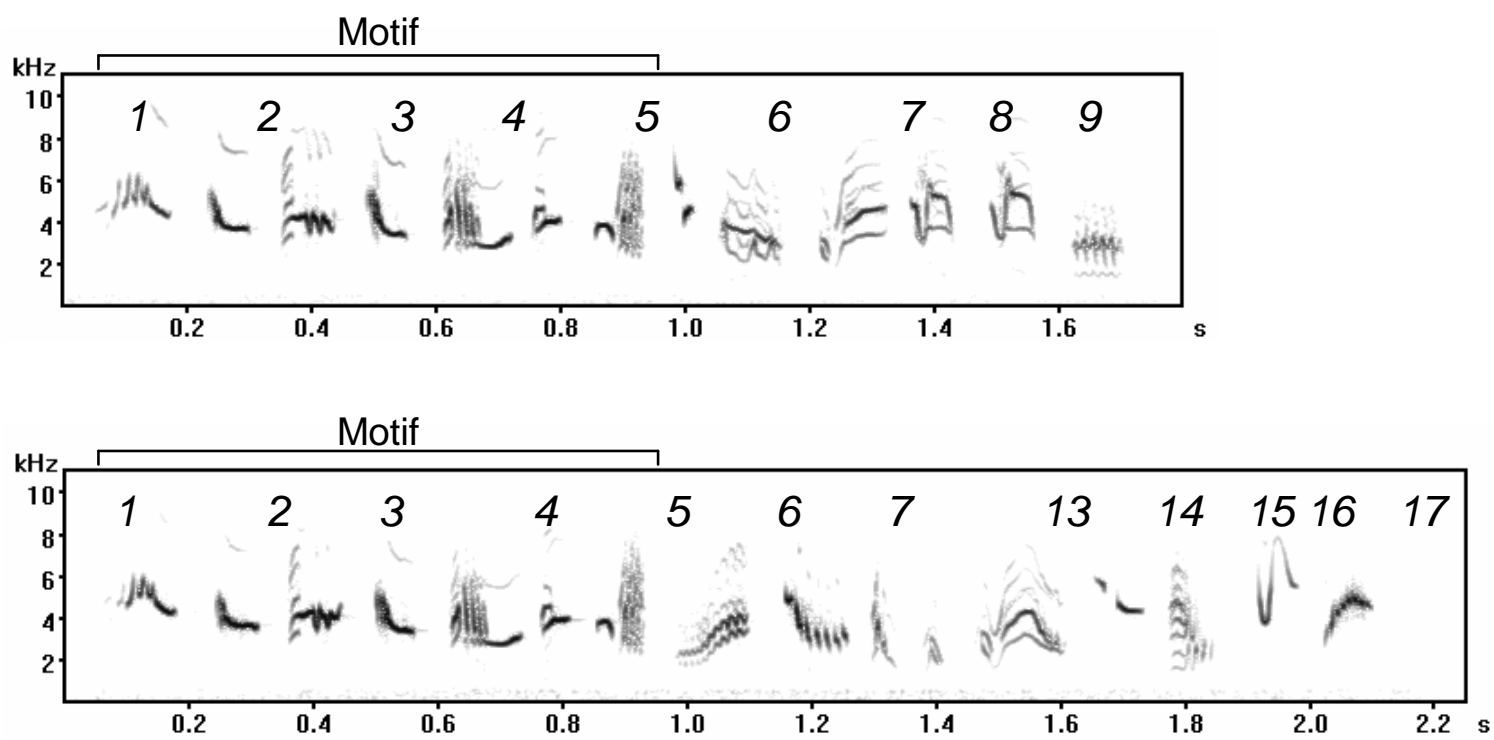
Figure 2

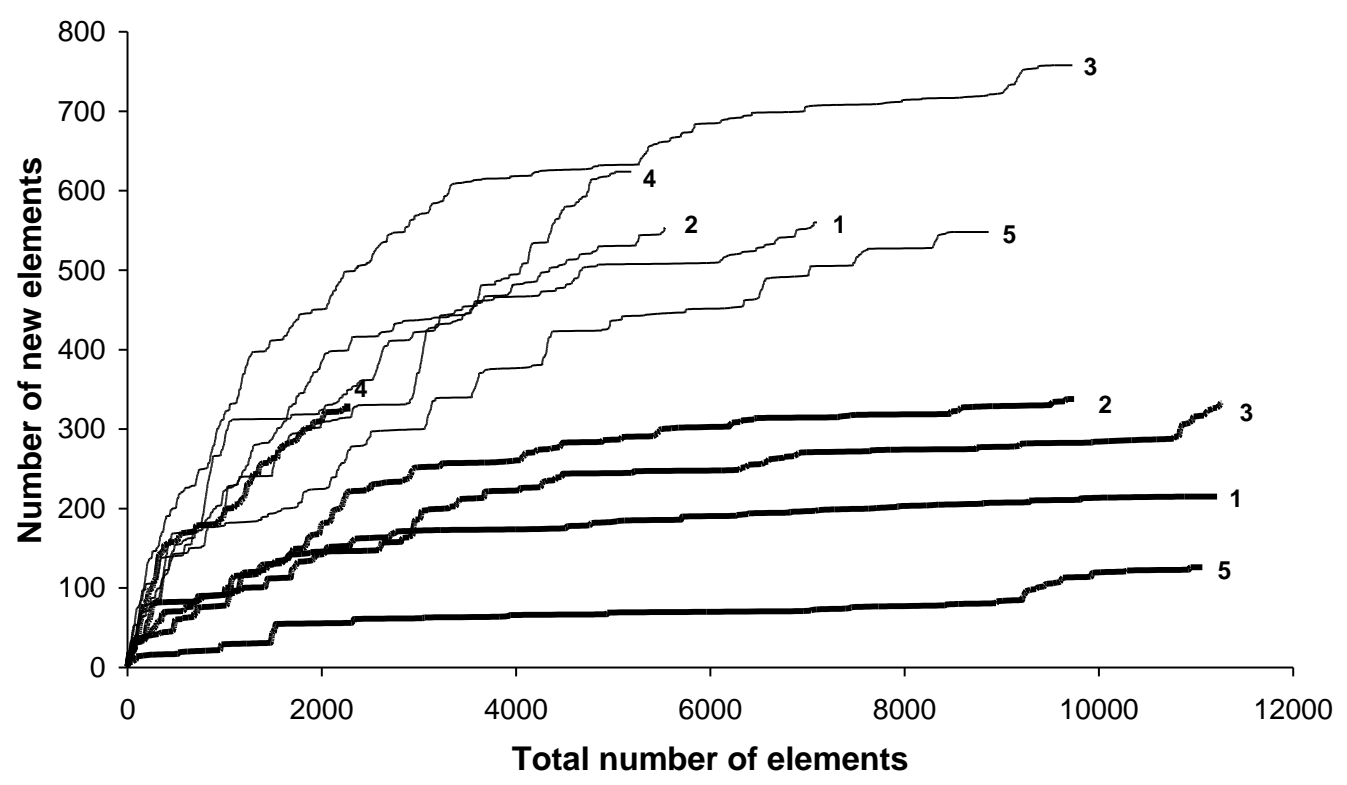


Figure 3a

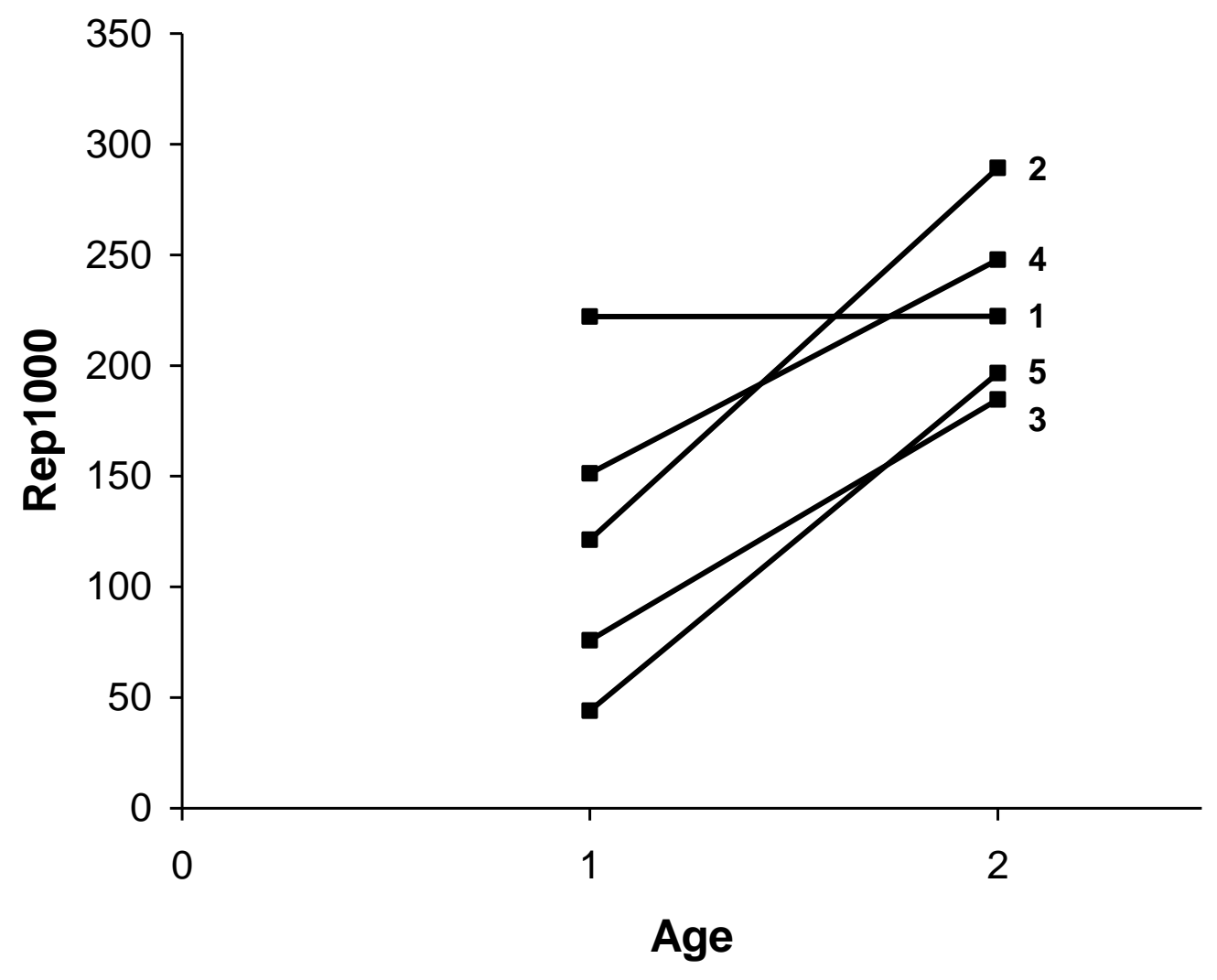


Figure $3 b$

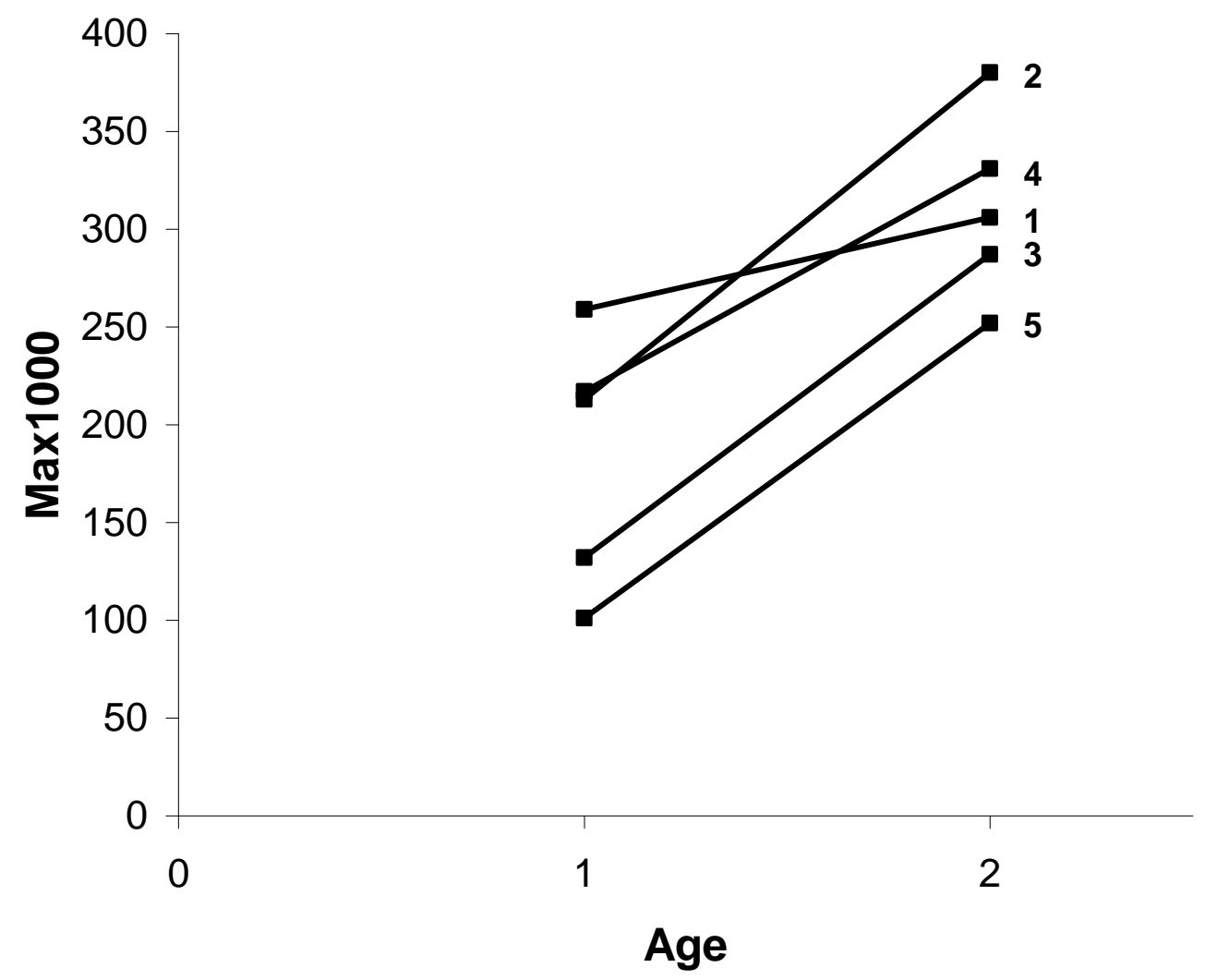


Figure 3c
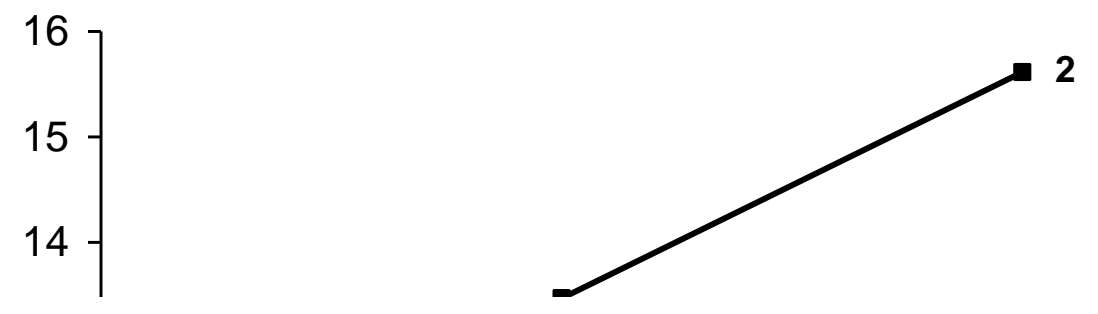

을 10

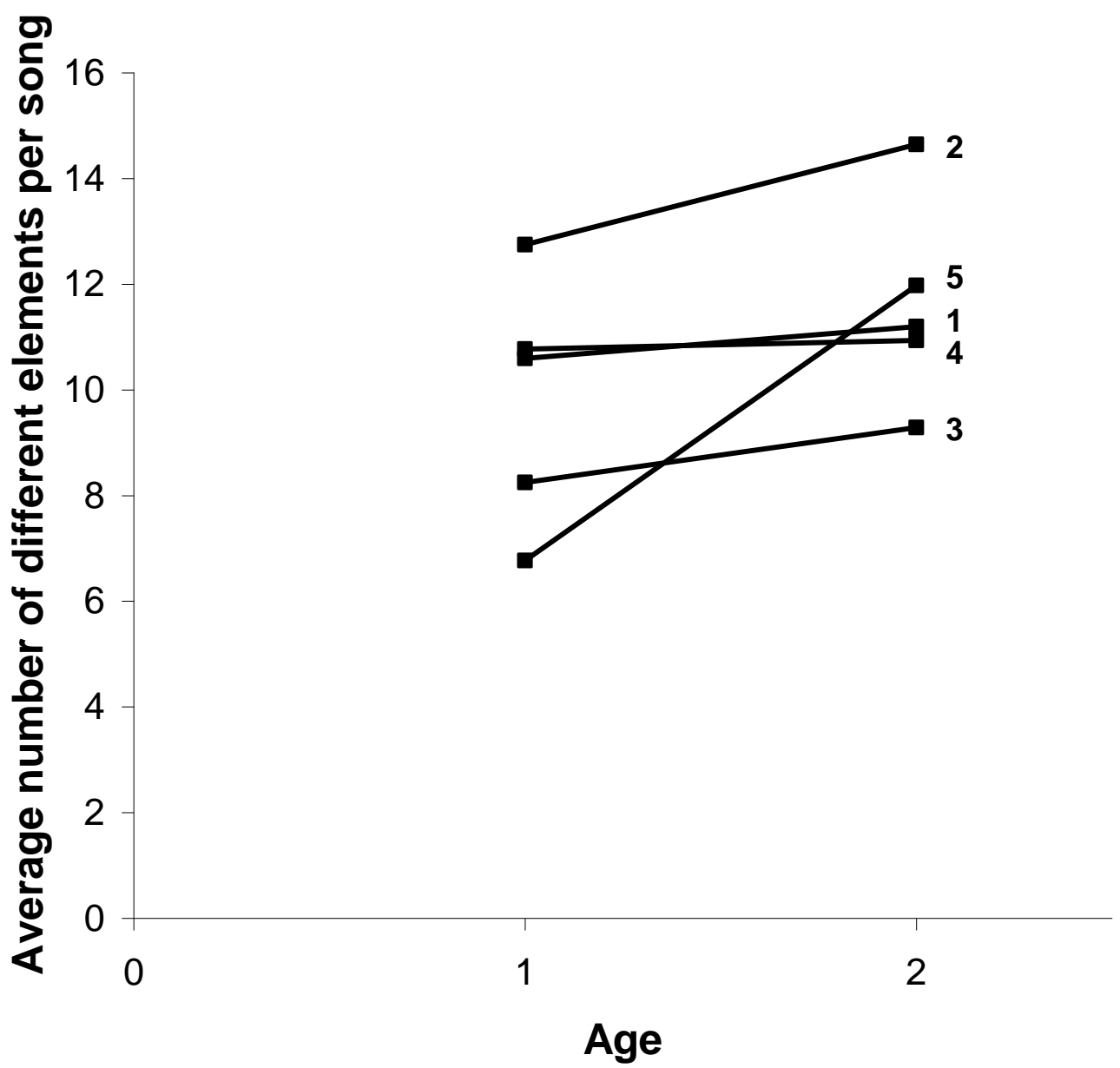

Figure $3 d$ 
Figure 4

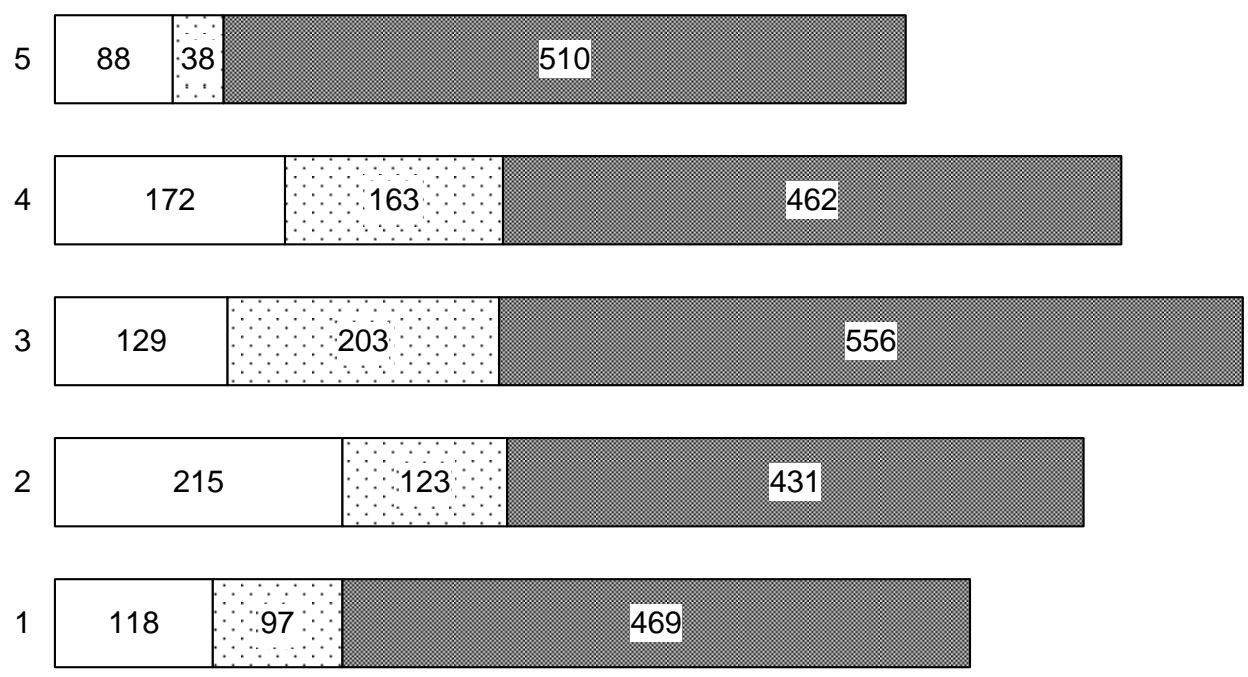

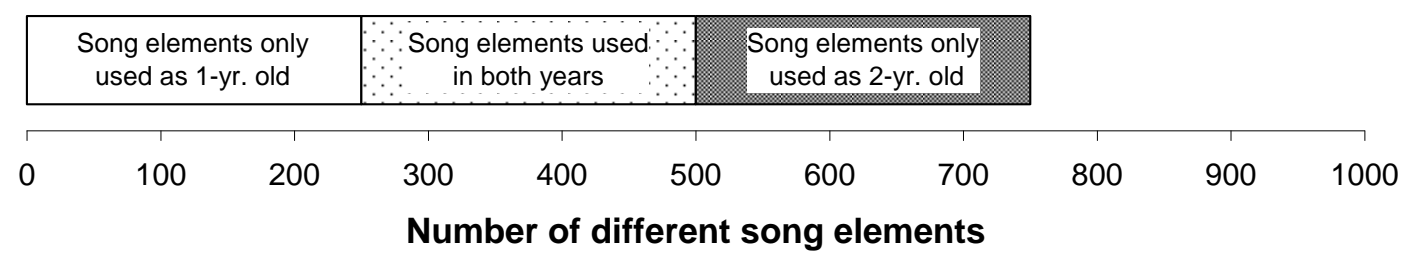

Figure 5 


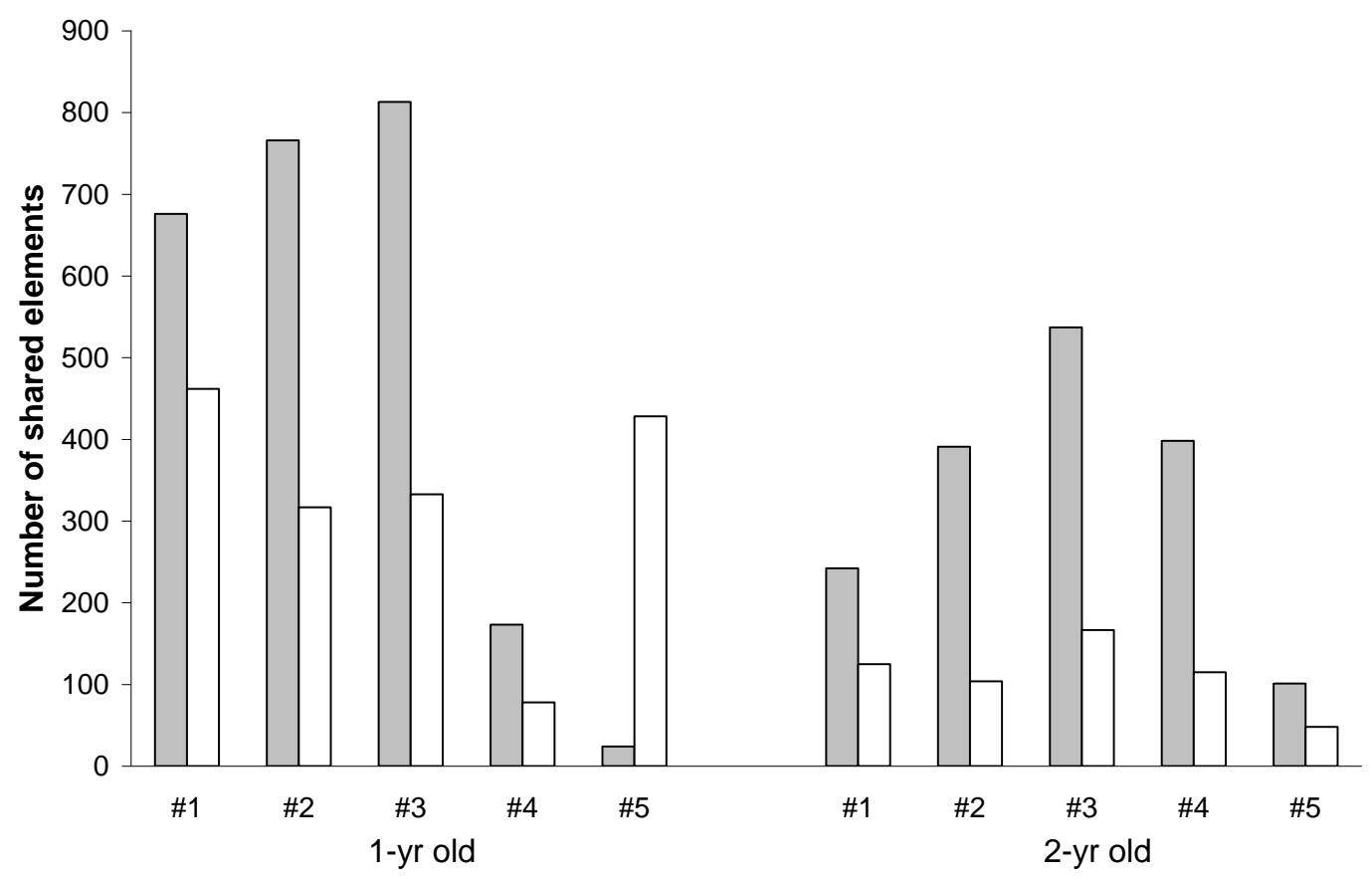

